\title{
Personal computers spur drive to keep control over copyright
}

[SAN DIEGO] Grassroots efforts to control the copyright of research articles are springing up across the United States as researchers seek to increase their direct involvement in electronic publishing.

Some universities are studying how to maintain the copyright for their published research, while others have begun the electronic publication of all graduate theses and dissertations. There are also calls for a national repository to hold a portion of the overall copyright of published research.

The initiatives are being driven partly by the rising costs of journals and growing concerns over the consolidation of companies that publish them. But academic librarians say that researchers' personal computers are the real catalysts for change over the control of copyright of scholarly work.

"The machines on the desktop empower faculty and researchers to control scholarly information in a way they have never had before," says Scott Bennett, Yale University's librarian.

One of the main issues of concern is how to maintain the peer-review certification process that makes today's research strong, while allowing electronic publishing to disseminate scholarly work more widely.

This dilemma has given rise to the concept of 'decoupling' the scientific certification process from the publishing of research articles. How this will be accomplished in the expanding arena of electronic publishing has yet to be determined.

Currently, most journals - and the societies that publish them - require authors to give full copyright to the publication. In other cases, the copyright reverts to the author or authors after it is first published.

There is a growing movement among researchers and universities to fight to retain copyright after the initial publication. "We pay all the costs of generating knowledge, and then we have to pay to buy it back - with an outrageous inflation rate in the cost of journals," says David E. Shulenburger, provost at the University of Kansas.

Last month, at a meeting of the Association of Research Libraries, Shulenburger proposed the setting up of a national repository to hold a portion of the copyright material in academic articles from 90 days after initial journal publication. The National Electronic Article Repository, as he calls it, would facilitate the dissemination of academic work, hopefully keeping costs down while increasing access to knowledge.

The California Institute of Technology (Caltech) in Pasadena has set up a website to collect the opinions of faculty members and students about its plans early next year to assert new controls over the copyright of research. For ten years, Caltech has owned the copyright of all research produced there, but it has not enforced that ownership, says

\section{Germany restores funds to grant agencies}

[MUNICH] Germany's coalition government is to make up a shortfall in the budgets of the Max Planck Society (MPS) and the Deutsche Forschungsgemeinschaft (DFG), the university research grants agency, and add an extra five per cent to each in 1999.

Edelgard Bulmahn, the research minister, last week agreed the increases with representatives of Germany's 16 Länder (states), which contribute half of the budgets. Assuming parliamentary approval, the MPS will receive a DM90 million (US\$53 million) increase in 1999, bringing its budget to DM1.66 billion. The DFG will receive DM100 million more, raising its budget to DM2.2 billion.

Since 1990, the MPS and the DFG have received an annual five per cent budget increase to build up the science base of eastern Germany. But this year's increase was capped by parliament at 3.5 per cent.

At the time, Hubert Markl, the MPS president, warned that the resulting shortfall could result in the closure of institutes (see Nature 392, 3; 1998). Markl says he is "delighted" by the increase, but remains cautious as the budgets may be capped again by parliament next year.

This is unlikely, however, as the political environment is now more friendly to science. In his inaugural speech to parliament this month, Chancellor Gerhard Schröder reaffirmed a promise to double federal spending on research and education in the next five years.

The MPS wants the money to continue its expansion programme in eastern Germany, called 'Aufbau Ost'. Last week, its senate approved the foundation of an Institute of Ethnological Research in Halle, the twentieth institute in the new Länder.

Germany's five new Länder now have a similar density of Max Planck institutes to the 11 west German Länder. But scientists still work in poor facilities as new buildings are not yet complete.

Quirin Schiermeier
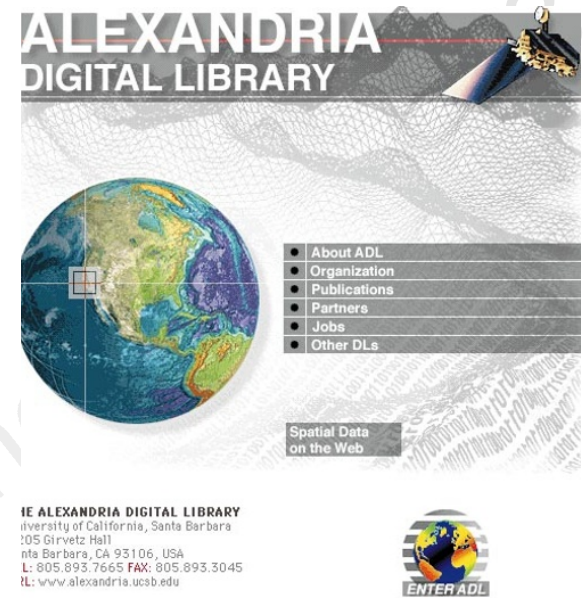

New world: the growth of digital libraries is leading to a global rethink of copyright issues.

Steven E. Koonin, the university's provost.

After reviewing the discussions, Caltech plans to consider a system whereby the university would retain copyright control after initial publication. This would pit the institution against professional societies, which demand copyright and prohibit subsequent posting of articles on other websites.

To "maximize the distribution of intellectual property at universities, we have to take control of the property right of the work we produce, retain it and use it," says Charles E. Phelps, provost at the University of Rochester in New York.

Nearly two years ago, in the first such action in the country, Virginia Polytechnic Institute and State University took the bold step of requiring that all graduate theses and dissertations be filed electronically at the university library.

There are methods of initially blocking access to research that may be patented, but once such rights have been secured the theses and dissertations are available through the university's library.

Martin Blume, editor-in-chief of the American Physical Society's 11 publications, recently proposed that journals be given licences to publish articles, with the copyright being kept by the authors.

Stefan Von Holtzbrinck, a director of Macmillan Magazines, the publisher of Nature, says it is important for publishers of major journals to retain copyright to ensure they can continue to add value to submitted manuscripts through the peer-review process. But he is aware that the scientific community is keen "to ensure that its efforts won't be exploited by a publisher who does not add anything to articles”. RexDalton 